\title{
STUDI KELAYAKAN DAN EFISIENSI USAHA PENGASAPAN IKAN DENGAN ASAP CAIR LIMBAH PERTANIAN
}

\author{
Fronthea Swastawati \\ Fakultas Perikanan dan Ilmu Kelautan Universitas Diponegoro Semarang \\ E-mail: fronthea@yahoo.com
}

\section{Diterima 22 April 2011/Disetujui 9 Juni 2011}

\begin{abstract}
The objective of this research is to assess feasibility study of smoking fish bussines with liquid smoke agriculture waste as one of the alternative substitute to traditional smoking industries which have some weakneses in term of safety and enviromental. The Method used was description case study with questionnaire as instrument to obtain data. Estimation model of double regression analysis was applied to interpretate the results. The production liquid of smoked using agriculture waste were feasible values NPV of 108.461.057; IRR $(\%)=33,29 \%$; and PP = 2,8 year. Whereas Catfish, Skipjack, and Stingray smoked fish values of NPV $=63,35 ; \mathrm{IRR}=24,74 ; \mathrm{PP}=3,31 ; \mathrm{NPV}=54,31 ; \mathrm{IRR}=23,33 ; \mathrm{PP}=3,35 ; \mathrm{NPV}=45,07 ; \mathrm{IRR}=21,50 ; \mathrm{PP}=$ 3,46 respectively. The production of liquid smoked agriculture waste and smoked fish using liquid smoked agriculture waste were as it produce feasible excellence, safety product and acceptable to consumers and also profitable. Break Event Point also could be reached in a short period of time.
\end{abstract}

Keywords : feasiblity study, liquid smoked, agriculture waste

Ikan asap merupakan salah satu produk olahan yang digemari konsumen baik di Indonesia maupun di mancanegara karena rasanya yang khas dan aroma yang sedap spesifik. Proses pengasapan ikan di Indonesia pada mulanya masih dilakukan secara tradisional menggunakan peralatan yang sederhana serta kurang memperhatikan aspek sanitasi dan hygienis sehingga dapat memberikan dampak bagi kesehatan dan lingkungan. Kelemahan-kelemahan yang ditimbulkan oleh pengasapan tradisional antara lain kenampakan kurang menarik (hangus sebagian), kontrol suhu sulit dilakukan dan mencemari udara (polusi).

Untuk mengatasi masalah ini di negara-negara maju seperti Canada, Jerman, Inggris, Jepang, dan lain-lain telah memanfaatkan teknologi kondensasi yang menghasilkan asap cair. Asap cair mempunyai kelebihan-kelebihan antara lain mudah diaplikasikan, konsentrasi asap dapat diatur sesuai selera konsumen, produk mempunyai kenampakan yang seragam dan ramah lingkungan. Hal lain yang penting adalah bahwa asap cair tidak hanya berperan dalam membentuk karakteristik sensoris tetapi juga dalam hal jaminan keamanan pangan. (Guilén and Cabo, 2004; Suñen, et al., 2001; Kris B, de Roos, 2003; Darmadji, 2006; Bortolomeazzi, et al, 2007; Martinez, et al, 2007).

Proses pengasapan ikan pada mulanya masih dilakukan secara tradisional yang ditujukan untuk pengawetan. Dalam perkembangannya asap cair ditujukan untuk memberikan efek terhadap aroma, rasa dan warna yang spesifik. Beberapa jenis limbah pertanian seperti bonggol jagung, sekam padi, ampas tebu, kulit kacang tanah, tempurung dan sabut kelapa, perdu, kayu mangrove, sejenis pinus, dan lain-lain, berpotensi memiliki kandungan senyawa antioksidan fenol dan antibakteri yang dapat mengawetkan dan memberi rasa sedap spesifik pada produk ikan asap (Guillen dan Cabo, 2004; Doherty and Cohn, 2000; Suharto, 1991; Witono, 2005).

Pemanfaatan asap cair sebagai alternatif metoda pengasapan ikan yang murah, mudah diterapkan, dan ramah lingkungan sudah saatnya diterapkan di Indonesia, karena sebagai negara agraris Indonesia memiliki kekayaan alam flora yang menghasilkan limbah kayu yang dapat dimanfaatkan sebagai bahan baku asap cair. Oleh sebab itu penelitian ini mengkaji pemanfaatan limbah pertanian yang dapat dijadikan 
sebagai bahan baku asap cair dan sekaligus kemungkinan penerapannya pada industri pengasapan ikan di Indonesia. Selanjutnya disosialisasikan pada industri pengolahan ikan di Indonesia melalui berbagai kegiatan pengabdian masyarakat dan publikasi.

\section{TINJAUAN PUSTAKA}

\section{Studi Kelayakan}

Aspek ekonomi sangat penting artinya dalam suatu kegiatan usaha. Hal-hal yang berkaitan dengan modal, perhitungan biaya operasional, biaya peralatan, gaji karyawan, keuntungan perusahaan dan lain-lain harus diperhatikan dengan cermat. Tidak terkecuali pada unit usaha pengasapan ikan. Berikut ini akan diuraikan beberapa teori yang mendukung aspek ekonomi usaha pengasapan ikan.

Salah satu cara mengembangkan suatu usaha adalah dengan melakukan investasi baru. Sebelum melakukan investasi, perlu dilakukan studi kelayakan untuk memperkirakan apakah investasi yang akan dilakukan layak atau tidak, salah satunya ditinjau dari sisi keuangan. Pada umumnya ada empat metode yang biasa dipertimbangkan untuk dipakai dalam penilaian aliran kas dari suatu investasi, yaitu metode Payback Period, Net Present Value, Internal Rate of Return dan Profitability Index (Umar, 2000).

\section{Metode Payback Periode (PP)}

Payback Periode adalah suatu periode yang diperlukan untuk menutup kembali pengeluaran investasi (initial cash investment) yang menggunakan aliran kas, dengan kata lain payback period merupakan rasio antara 'initial cash investment' dengan 'cash inflow'-nya, yang hasilnya merupakan satuan waktu. Selanjutnya nilai rasio ini dibandingkan dengan maximum payback period yang dapat diterima (Umar, 2000).

Jika 'payback period' lebih pendek waktunya dari 'maximum payback period'-nya maka usulan investasi dapat diterima. Metode ini cukup sederhana sehingga mempunyai beberapa kelemahan antara lain tidak memperhatikan konsep nilai waktu dari uang, disamping juga tidak memperhatikan aliran kas masuk setelah payback (Umar, 2000). Untuk mengatasi kelemahan karena mengabaikan nilai waktu uang, metode perhitungan payback period dicoba diperbaiki dengan mempresent-valuekan arus kas, dan dihitung periode paybacknya. Cara ini disebut sebagai discounted payback period (Husnan, 1997).

\section{Metode Internal Rate of Return (IRR)}

Metode ini digunakan untuk mencari tingkat bunga yang menyamakan nilai sekarang dari arus kas yang diharapkan di masa datang, atau penerimaan kas, dengan mengeluarkan investasi awal (Umar, 2000). IRR adalah salah satu metode untuk mengukur tingkat investasi.

dimana :

Rumus yang dipakai: Io $=\sum_{t=1}^{n} \frac{C F t}{(1+I R R)^{t}}$

$\mathrm{t}=$ tahun ke

$\mathrm{n}=$ jumlah tahun

Io $=$ nilai investasi awal

$\mathrm{CFt}=$ arus kas bersih

IRR = tingkat bunga yang dicari harganya

Nilai IRR dapat dicari dengan cara coba-coba (trial and error). Caranya, hitung nilai sekarang dari arus kas dari suatu investasi dengan menggunakan suku bunga yang wajar, misalnya $10 \%$, lalu bandingkan dengan biaya investasi, jika nilai investasi lebih kecil, maka dicoba lagi dengan suku bunga yang lebih tinggi demikian seterusnya sampai biaya investasi menjadi sama besar. Sebaliknya, dengan suku bunga wajar tadi nilai investasi lebih besar, coba lagi dengan suku bunga yang lebih rendah sampai mendapat nilai investasi yang sama besar dengan nilai sekarang (Umar, 2000). Decisión rule metode ini adalah "terima investasi yang diharapkan memberikan IRR $\geq$ tingkat bunga yang dipandang layak". Kelemahan metode IRR ini adalah bahwa $i$ yang dihitung akan merupakan angka yang sama untuk setiap tahun usia ekonomis dan bisa diperoleh $i$ yang lebih dari satu angka. Kelemahan lainnya adalah pada saat perusahaan harus memilih proyek yang bersifat mutually exclusive (Husnan, 1997)

Kriteria penilaian: Jika IRR yang didapat ternyata lebih besar dari 'rate of return' yang ditentukan maka investasi dapat diterima.

\section{Metode Net Present Value (NPV)}

Net Present Value yaitu selisih antara Present Value dari investasi dengan nilai sekarang dari penerimaan-penerimaan kas bersih (aliran kas operasional maupun aliran kas terminal) di masa yang akan datang (Umar, 2000). Untuk menghitung nilai sekarang perlu ditentukan tingkat bunga yang relevan.

NPV $>0$ berarti proyek tersebut dapat menciptakan cash inflow dengan persentase lebih besar dibandingkan opportunity cost modal yang ditanam- 
kan. Apabila NPV $=0$, proyek kemungkinan dapat diterima karena cash inflow yang akan diperoleh sama dengan opportunity cost dari modal yang ditanamkan. Jadi semakin besar nilai NPV, semakin baik bagi proyek tersebut untuk dilanjutkan (Rangkuti, 2004).

Perhitungan NPV memerlukan dua kegiatan penting, yaitu : (1) menaksir arus kas, dan (2) menentukan tingkat bunga yang dipandang relevan.

\section{Metode Profitability Index (PI)}

Metode ini digunakan dengan menghitung perbandingan antara nilai sekarang (dari penerimaanpenerimaan kas bersih di masa yang akan datang) dengan nilai sekarang dari investasi. Kriteria ini erat hubungannya dengan kriteria NPV, Jika NPV suatu proyek dikatakan layak (NPV $>0$ ), maka menurut kriteria PI juga layak (PI $>1)$ karena keduanya variabel yang sama. Kelemahan metode ini adalah metode ini akan selalu memberikan keputusan yang sama dengan NPV kalau dipergunakan untuk menilai usulan investasi yang sama. Tetapi kalau dipergunakan untuk memilih proyek yang mutually exclusive, metode PI kontradiktif dengan NPV (Husnan, 1997).

\section{Titik Pulang Pokok (Break Even Point)}

BEP adalah suatu alat analisis yang digunakan untuk mengetahui hubungan antar beberapa variabel di dalam kegiatan perusahaan, seperti luas produksi atau tingkat produksi yang dilaksanakan, biaya yang dikeluarkan, serta pendapatan yang diterima. Pendapatan perusahaan merupakan penerimaan karena kegiatan perusahaan, sedangkan biaya operasinya merupakan pengeluaran yang juga karena kegiatan perusahaan. Biaya operasi ini terbagi atas tiga bagian, yaitu biaya tetap, biaya variabel, dan biaya semi variabel.

\section{Asap Cair dan Ikan Asap}

Pengasapan adalah salah satu metode pengawetan ikan yang merupakan kombinasi proses-proses penggaraman (brinning), pemanasan (cooking), dan pengasapan itu sendiri (smoking). Metode yang digunakan adalah dengan penerapan asap cair karena memiliki kelebihan-kelebihan yang tidak dimiliki oleh pengasapan tradisional yaitu mudah diaplikasikan dalam konsentrasi yang rendah sehingga lebih hemat. Di samping itu komponen karsinogenik dapat dipisahkan, efek antioksidan dan antimikrobanya juga lebih menonjol. (Clucas and Ward, 1996; Ismanadji, 1989; Suñen, 2001; Setiawan et al, 1997).
Pada dasarnya hampir semua jenis ikan seperti Bandeng, Tenggiri, Tuna, Kakap, Mujair, Nila, Lele dan lain-lain dapat diasapi, namun ikan-ikan yang populer dan biasa diasapi sampai saat ini adalah ikan laut yang berlemak tinggi seperti ikan Tuna, Tongkol, Manyung, Pari, dan Kembung, karena jenis ikan ini memiliki kekhasan masing-masing bila diasapi. Ikan air tawar yang sering diasapi antara lain adalah ikan Lele dan Belut. Apapun jenis ikan yang digunakan, sebagai bahan baku ikan asap harus dipilih ikan yang betul-betul segar agar dapat menghasilkan ikan asap yang berkualitas baik. (Swastawati. 1997).

Proses pengasapan ikan meliputi tahap-tahap penyiangan dan pencucian (splitting dan cleaning), penggaraman (salting), pengeringan I (drying I), perendaman dalam asap cair (dipping), pengeringan II (drying II) pemanasan (heating) dan pengemasan (packing) (Swastawati. 1997).

\section{METODE PENELITIAN}

\section{Sampel dan Pengumpulan Data}

Pada penelitian ini objek yang digunakan adalah 100 responden yang mewakili masyarakat Semarang dengan kasus pola konsumsi dan minat beli terhadap ikan asap. Metode pengumpulan data untuk memperoleh data primer dalam penelitian ini adalah metode observasi (pengujian alat) dan wawancara langsung terhadap para responden yang ada sebagai sampel, sedangkan pelaksanaannya dibantu dengan pemakaian daftar kuesioner sebagai alat untuk pengumpul data. Analisa data sangat ditentukan oleh sifat atau karakteristik data. Untuk analisis deskriptif dalam penelitian ini digunakan rerata $(\bar{x})$ dan standar deviasi, untuk studi kelayakan dan strategi pemasaran dilakukan analisa regresi (Santoso, 2001).

\section{Metode Deskriptif}

Metode deskriptif yang digunakan dalam riset ini bersifat studi kasus. Tujuan studi kasus adalah untuk memberikan gambaran secara detil tentang sifatsifat dan karakter yang khas dari suatu kasus, sehingga dapat digunakan sebagai kontrol ilustrasi dalam perumusan masalah, penggunaan statistik dalam menganalisa data serta cara-cara perumusan generalisasi dan kesimpulan (Nasir, 2005). 


\section{Uji Validitas dan Reliabilitas}

Uji Validitas berfungsi untuk mengukur valid tidaknya suatu kuesioner. Kuesioner dianggap valid jika pertanyaan pada kuesioner mampu mengungkapkan sesuatu yang akan diukur oleh kuesioner tersebut, dengan demikian pada prinsipnya uji validitas berguna untuk mengukur apakah pertanyaan yang diajukan dalam kuesioner yang telah dibuat betul-betul mampu mengukur apa yang hendak diteliti. Kuesioner akan dianggap valid apabila koefisien $r$ hitung lebih besar daripada $r$ tabel (dilihat dari Corrected total item correlation pada output SPSS). Koefisien korelasi yang tinggi menunjukkan kesesuaian antara fungsi ukur tes secara keseluruhan (Ghozali, I. 2001). Uji reliabilitas adalah alat untuk mengukur suatu kuesioner yang merupakan indikator dari suatu variabel. Kuesioner dianggap reliabel apabila jawaban dari pertanyaan yang diajukan konsisten.. Pada program SPSS terdapat fasilitas perhitungan pengukuran reliabilitas melalui statistik Cranbach Alpha $(\alpha)$ lebih besar dari 0,60 (Ghozali, I. 2001). Pengujian reliabilitas dilakukan dengan membandingkan nilai Cronbach alpha dengan batas kritisnya (cut of value). Nilai Cronbach alpha $(\alpha)$ suatu variabel dikatakan reliabel bila nilai $\alpha$ lebih dari 0,60 (cut of value).

Pengumpulan data primer dilakukan dengan simple random sampling. Populasi responden adalah masyarakat umum yang tinggal di wilayah Kota Semarang. Pengambilan sampel dilakukan dengan metode acak sederhana dimana semua individu memperoleh peluang yang sama untuk dijadikan sampel. Jumlah penduduk Kota Semarang mencapai 1.389.421 jiwa (Pemerintah Kota Semarang, 2006).

Menurut Suparmoko (1995), penentuan jumlah sampel dapat ditentukan dengan rumus:

dimana:

$$
n=\frac{N Z^{2} p(1-p)}{N d^{2}+Z^{2} p(1-p)}
$$

$\mathrm{n}=$ banyaknya anggota sampel

$\mathrm{N}=$ jumlah anggota dalam populasi

$\mathrm{Z}=$ area dalam kurva normal dengan selang kepercayaan $95 \%(1,96)$

$\mathrm{d}=$ prosentase varian $(0,5)$

$\mathrm{d}=$ kesalahan maksimum yang dapat diterima $(10 \%)$.

$$
\begin{aligned}
n & =\frac{1.389 .421(1,96)^{2}(0,5)(1-0,5)}{1.389 .421(0,1)^{2}+(1,96)^{2} 0,5(1-0,5)} \\
& =\frac{1.334 .399,93}{13.894,21+0,9604}
\end{aligned}
$$

$$
\begin{aligned}
& =\frac{1.334 .399,93}{13.895,1704} \\
& =96,03 \text { dibulatkan menjadi } 100
\end{aligned}
$$

Jumlah responden dalam penelitian ini adalah 100 orang.

\section{Studi Kelayakan}

Sebagai pelengkap dalam analisis secara ekonomi, dilakukan analisis perhitungan studi kelayakan yang terdiri dari Net Present Value (NPV); Break Event Point (BEP); Internal Rate of Return (IRR) serta Pay Back Period (Rangkuti, F., 2004).

\section{Internal Rate of Return (IRR)}

Metode Internal Rate of Return digunakan untuk mencari tingkat bunga yang menyamakan nilai sekarang dari arus kas yang diharapkan di masa datang, atau penerimaan kas, dengan mengeluarkan investasi awal (Umar, 2000).

Rumus yang dipakai seperti yang di bawah ini: Io $=\sum_{t=1}^{n} \frac{C F t}{(1+I R R)^{t}}$

dimana :

$\mathrm{t}=$ tahun ke

$\mathrm{n}=$ jumlah tahun

Io $=$ nilai investasi awal

$\mathrm{CFt}=$ arus kas bersih

IRR = tingkat bunga yang dicari harganya

\section{Net Present Value (NPV)}

Net Present Value selisih antara Present Value dari investasi dengan nilai sekarang dari penerimaanpenerimaan kas bersih (aliran kas operasional maupun aliran kas terminal) dimasa yang akan datang. Untuk menghitung nilai sekarang perlu ditentukan tingkat bunga yang relevan (Umar, 2000).

Rumus :

$$
\mathrm{NPV}=\sum_{t=1}^{n} \frac{C F t}{(1+I R R)^{t}}-I o
$$

dimana :

$\mathrm{CFt}=$ aliran kas per tahun pada periode $\mathrm{t}$

Io $=$ investasi pada tahun 0

$\mathrm{K}=$ suku bunga (discount rate)

Kriteria Penilaian :

- Jika NPV >0, maka usulan proyek diterima

- Jika NPV $<0$, maka usulan proyek ditolak

- Jika NPV $=0$, maka nilai perusahaan tetap walau usulan proyek diterima ataupun ditolak. 


\section{Pay Back Periode (PP)}

Pay Back Periode adalah suatu periode yang diperlukan untuk menutup kembali pengeluaran investasi (initial cash investment) yang menggunakan aliran kas, dengan kata lain PP merupakan rasio antara initial cash investment dengan cash inflow-nya, yang hasilnya merupakan satuan waktu. Selanjutnya nilai rasio ini dibandingkan dengan maksimum PP yang dapat diterima Rangkuti (2004).

Rumus :

Payback Period $=\frac{\text { nilai investasi }}{\text { kas masuk bersih }} \times 1$ tahun

Kriteria penilaian: Jika PP lebih pendek waktunya dari “maksimum PP"-nya maka usulan investasi dapat diterima.

\section{Break Event Point (BEP)}

Rumus BEP

BEP merupakan keadaan dimana penerimaan pendapatan perusahaan (total revenue) yang disingkat TR adalah sama dengan biaya yang ditanggungnya (total cost) yang disingkat TC. TR merupakan perkalian jumlah unit barang yang terjual dengan harga satuannya, sedangkan TC merupakan penjumlahan dari biaya tetap dan biaya variabelnya. Rumus BEP dapat dituliskan sebagai berikut:

$$
\mathrm{TR}=\mathrm{TC} \text { atau Q.P }=\mathrm{a}+\mathrm{b} . \mathrm{X}
$$

dimana :

$\mathrm{Q}=$ tingkat produksi (unit)

$\mathrm{P}=$ harga jual per unit

$\mathrm{a}=$ biaya tetap

$\mathrm{b}=$ biaya variabel

Untuk mencari jumlah yang diproduksi agar titik mencapai impasnya adalah :

$$
\mathrm{X}=\frac{\mathrm{a}}{\mathrm{p}-\mathrm{b}}
$$

Jika yang akan dicari adalah total harga agar mencapai titik impas, maka rumusnya adalah :

$$
\begin{aligned}
X . P & =\frac{a}{(p-b) / p} \\
& =\frac{a}{1-b / p}
\end{aligned}
$$

\section{HASIL DAN PEMBAHASAN}

\section{Hasil Uji Validitas Terhadap Variabel Produk, Harga, Kemasan dan Rasa}

Berdasarkan pengolahan data menggunakan SPSS dapat disimpulkan bahwa pertanyaan pada variabel produk adalah valid karena $\mathrm{r}$ hitung $=\mathrm{X} 1.1$ $0,4089+\mathrm{X} 1.20,3788+\mathrm{X} 1.30,3702+\mathrm{X} 1.40,5069$ $>\mathrm{r}$ tabel $=0,195$. Pertanyaan pada variabel harga adalah valid, karena $r$ hitung $=$ X2.1 $0,3847+\mathrm{X} 2.2$ $0,4931+\mathrm{X} 2.30,3874>\mathrm{r}$ tabel $=0,195$. Pertanyaan pada variabel kemasan adalah valid, karena $r$ hitung $=$ $\mathrm{X} 3.10,4132+\mathrm{X} 3 \cdot 20,4754+\mathrm{X} 3 \cdot 30,4496>\mathrm{r}$ tabel $=0,195$. Pertanyaan pada variabel rasa adalah valid, karena $\mathrm{r}$ hitung $=\mathrm{X} 4.10,3824+\mathrm{X} 3.20,4508+\mathrm{X} 4.3$ $0,4847>\mathrm{r}$ tabel $=0,195$.

\section{Pengujian Reliabilitas}

Berdasarkan hasil pengujian tersebut menunjukkan bahwa semua variabel yang digunakan dalam penelitian ini memiliki nilai Cronbach alpha $(\alpha)$ lebih besar dari 0,60. variabel produk memiliki nilai Cronbach alpha $(\alpha)$ sebesar 0,6342 , variabel harga memiliki nilai nilai Cronbach alpha $(\alpha)$ sebesar 0,6104, variabel kemasan sebesar 0,6339, variabel rasa memiliki nilai 0,6152 , dan variabel minat beli konsumen memiliki nilai 0,7802 . Hal ini menyatakan bahwa semua variabel yang digunakan dalam penelitian bersifat reliabel.

\section{Studi Kelayakan}

\section{Analisis Kelayakan Usaha Produksi Asap Cair}

Parameter NPV (net Present Value), IRR (Internal Rate of Return) dan paybacks periods dapat digunakan untuk melakukan analisis usaha. Usaha produksi asap cair terbukti layak atau feasible. Hal itu dapat dilihat dari NPV yang positif, IRR yang relatif moderat dan payback periode yang kurang dari 3 tahun. Berikut gambaran mengenai analisis usaha produksi asap cair.

\section{Tabel 1. Analisis Usaha Produksi Asap Cair}

\begin{tabular}{|l|r|}
\hline Parameter & \\
\hline Modal investasi (Rp) & $145.000 .000,-$ \\
\hline Modal kerja tahun 1 (Rp) & $81.320 .000,-$ \\
\hline Harga produk (Rp/liter) tahun 1 & $200.000,-$ \\
\hline NPV (Rp), 12\%, 5 tahun & $108.461 .057,-$ \\
\hline IRR (\%) & $33.29 \%$ \\
\hline Payback periods (tahun) & 2.80 \\
\hline
\end{tabular}

Modal investasi yang dibutuhkan adalah $\mathrm{Rp}$ 145.000.000,- dimana paling banyak digunakan untuk investasi pengadaan kendaraan operasional. Sedangkan untuk tanah dan bangunan dilakukan dengan 
menyewa. Investasi untuk pengadaan mesin pembuat asap cair hanya Rp. 6.000.000,- yang dapat dipergunakan untuk memproduksi 1.200 liter asap cair per tahun. Konsentrat asap cair dijual dengan kemasan per botol 1 liter dan ditawarkan dengan harga Rp. 200.000/liter untuk tahun pertama. Kenaikan harga pertahun diasumsikan sebesar $5 \%$ per tahun, baik harga produk maupun biaya produksi dan administrasi usaha asap cair.

Dalam analisis NPV, usaha produksi asap cair menghasilkan nilai Rp. 108.461.057 untuk jangka waktu 5 tahun dan faktor suku bunga ditetapkan sebesar $12 \% /$ tahun. Nilai NPV yang positif menunjukkan bahwa apabila diakumulasikan antara biaya investasi dan keuntungan yang diperoleh dalam 5 tahun serta di-present value-kan, maka nilainya masih positif yang berarti memberikan keuntungan.

Sedangkan dalam analisis IRR, usaha produksi asap cair menghasilkan 33,29\%. Nilai tersebut relatif lebih besar dari suku bunga yang ditetapkan oleh Bank Indonesia (BI rate) dan discount factors yang ditetapkan (12\%). hal itu menunjukkan bahwa usaha produksi asap cair relatif feasible karena menghasilkan tingkat pengembalian lebih besar dari suku bunga yang berlaku secara umum. Sedangkan payback periods dari usaha ini adalah 2,8 tahun. Oleh karena itu, dapat diartikan bahwa lama pengembalian modal usaha produksi asap cair relatif tidak terlalu lama.

\section{Analisis Kelayakan Usaha Produksi Ikan Asap}

Alternatif usaha juga dapat dilakukan dengan memproduksi ikan asap. Adapun alternatif beberapa jenis ikan dapat dijadikan komoditas ikan asap antara lain ikan Tongkol, Manyung, Pari, Bandeng, dan Kembung. Secara garis besar, analisis usaha produksi beberapa jenis ikan asap adalah sebagai berikut :

Tabel 2. Analisis usaha beberapa jenis ikan asap

\begin{tabular}{|l|r|r|r|}
\hline \multicolumn{1}{|c|}{ Parameter } & Manyung & Tongkol & \multicolumn{1}{c|}{ Pari } \\
\hline Modal investasi (Rp juta) & 140 & 140 & 140 \\
\hline Modal kerja tahun 1 (Rp juta) & 333.2 & 256.8 & 240.8 \\
\hline Harga produk (Rp/kg) tahun 1 & 52.500 & 42.500 & 40.000 \\
\hline NPV (Rp juta), 12\%, 5 tahun & 63.35 & 54.31 & 45.07 \\
\hline IRR (\%) & 24.74 & 23.33 & 21.50 \\
\hline Payback periods (tahun) & 3.31 & 3.35 & 3.46 \\
\hline
\end{tabular}

Dalam tabel 2 di atas dapat dilihat bahwa modal investasi produksi ikan asap Rp. 140 juta, dimana dana terbesar dipergunakan untuk pengadaan kendaraan operasional. Sedangkan harga produk bervariasi mulai dari Rp. 35.000 sampai Rp. 60.000,- dimana dipengaruhi oleh harga bahan baku dan preferensi konsumen. Semakin tinggi harga bahan baku dan preferensi konsumen, maka harga produk yang ditawarkan semakin tinggi.

Dalam analisis NPV terlihat bahwa NPV untuk 5 tahun dengan discount factors $12 \%$ adalah berkisar Rp. 23,08 juta hingga Rp. 86,04 juta. Hal itu dapat diartikan bahwa usaha yang dilakukan positif, dimana suatu usaha dikatakan feasible bila nilai NPVnya positif. Sedangkan IRR berkisar antara 17-28 \% yang merupakan rate of return yang moderat dan lebih tinggi dari suku bunga yang ditetapkan. Oleh karena itu berdasarkan parameter IRR, maka usaha beberapa jenis ikan asap juga feasible. Sedangkan lama pengembalian modal berkisar 3,13-3,76 tahun sehingga tidak terlalu lama (moderat).

Sebagai pembanding dan untuk mengetahui tingkat efisiensinya, dilakukan analisis kelayakan usaha ikan asap tradisional. Survei dilakukan pada pengolah asap tradisional di wilayah Semarang, yaitu di Kelurahan Krobokan dan Kelurahan Tambak Lorok. Pengolah ikan asap tradisional memproduksi dua jenis ikan asap, yaitu manyung asap dan Pari asap. Ringkasan kelayakan usaha ikan asap tradisional adalah sebagai berikut:

\section{Tabel 3. Analisis usaha produksi ikan asap tradisional}

\begin{tabular}{|l|r|}
\hline \multicolumn{1}{|c|}{ Parameter } & \multicolumn{2}{c|}{ Keterangan } \\
\hline Modal investasi (Rp juta) & 25.5 \\
\hline Modal kerja tahun 1 (Rp juta) & 142.4 \\
\hline NPV (Rp juta), 12\%, 5 tahun & 5.2 \\
\hline IRR (\%) & 18 \\
\hline Payback periods (tahun) & 3.69 \\
\hline
\end{tabular}

Pada umumnya, memang kebutuhan modal untuk produksi ikan asap tradisional lebih kecil dibanding ikan asap cair. Namun, NPV, IRR dan payback periods usaha ikan asap cair terlihat lebih menguntungkan. Harga jual ikan manyung asap diasumsikan Rp. 2.500/potong dan harga jual ikan Pari asap $R p$ 2.000/potong. Dalam analisis ini, para pengolah ikan tradisional diasumsikan juga dikenakan pajak, meskipun pada kenyataannya para pengolah ikan asap tradisional merupakan pelaku ekonomi non formal yang seringkali tidak membayar pajak. Pada tahun pertama, keuntungan setelah pajak pengolah ikan tradisional sekitar Rp. 3 juta. Namun, apabila pajak tidak dihi- 
tung, maka keuntungan dapat mencapai Rp. 4,7 juta ditambah gaji tenaga kerja (biasanya ditangani rumah tangga sendiri) yang diperhitungkan sekitar Rp. 20,8 juta/tahun.

\section{KESIMPULAN DAN SARAN}

Penerapan asap cair sangat layak karena terbukti mempunyai keunggulan, keamanan dan dapat diterima oleh konsumen dengan hasil menguntungkan dan BEP dapat dicapai dalam waktu yang tidak terlalu lama. Strategi yang diterapkan adalah dengan jaminan keamanan, informasi gizi, harga terjangkau, promosi dan pengemasan yang baik. Jenis produksi, harga, kemasan dan rasa mempengaruhi tingkat penerimaan konsumen.

Ismanadji, Iskandar. 1989. Pengolahan Ikan Bandeng Asap dengan Menggunakan Almari Pengasapan (Smoking Cabinet). Direktorat Jendral Perikanan.

Jakarta.
Martinez, O.; Salmeron, J. ; Guillen, M.D. ; Casas, S. 2007. the Antioxidant Capacity of Smoke flavuoring Phenol by Crocin Bleaching Inhibition, DPPH Radical Scavenging and Oxidation Potential. Food Chemistry Journal. Italy.

Clucas, I.J., and A.R. Ward. 1996. Post Harvest Fisheries Development: Guide to Handling. Preservation Processing and Quality. Chatham Maritime. England.

Darmadji, P. 2006. Produksi Biopreservatif Asap Cair Cangkang Sawit dan Aplikasinya untuk Bidang Pangan, Hasil Perkebunan dan Kehutanan. Laporan Seminar Penggunaan Bahan Alami untuk Pengawetan Ikan. Balai Besar Riset dan Pengolahan Produk dan Bioteknologi Kelautan dan Perikanan dan ISPIKANI. Jakarta.

de Ros, Kris B. 2003. Effect of Texture and microstructure on Flavour Retention and Release. International Dairy Journal. Netherland.

Doherty and Cohn. 2000. Seed Dormancy in Red Rice (Oryza sativa) XI in Seed Science Research. Vol 10 Number and pp 415-421 (7). Commercial Liquid Smoke Elicits Germination. CAB I Publishing. http://www.cabi.com

Guillen, M. D. ; Cabo, N. 2004. Study of The Effects of Smoke Flavourings on The Oxidative Stability of The Lipids of Pork Adipose Tissue by Means of Fourier Transform Infrared Spectroscopy. Meat Science. Spain.

Gozali, I. 2001. Aplikasi Analisis Multivariate dengan Program SPSS. Badan Penerbit Universitas Diponegoro. Semarang.

Husnan, Suad. 1997. Manajemen Keuangan Teori dan Penerapan (Keputusan Jangka Panjang). BPFE. Yogyakarta.

\section{Mart} Textural and Physicochemical Changes in Salmon (Salmo salar) treated with Commercial Liquid Smoke Flavourings. Food Chemistry. Spain.

Nazir, M. 2005. Metode Penelitian. PT. Ghalia Indonesia. Jakarta.

Santoso, S. 2001. Mengatasi Berbagai Masalah Statistik dengan SPSS versi 11.5. PT : Elex Media Komputindo. Jakarta.

Setiawan, I., Darmadji, P., Raharjo, B. 1997. Pengawetan Ikan dengan Pencelupan dalam Asap Cair. Prosiding Seminar Nasional Teknologi Pangan. Buku I. Perhimpunan Ahli Teknologi Pangan Indonesia. Jakarta. Indonesia.

Suharto. 1991. Teknologi Pengawetan Pangan. Penerbit Rineka Cipta. Malang.

Suñen, E., Galian, B.G., Aristimuño, C. 2001. Antibacterial Activity of Smoke Wood Condensates Againts Aeromonas hydrophila, Yersinia enterocolitica and Listeria monocytogenes at Low Temperature. Food Microbiology. Italy.

Swastawati, F. 1997. Pengasapan Ikan. Universitas Negeri Diponegoro. Semarang.

Umar, Husein. 2000. Research Methods in Finance and Banking. PT. Gramedia Pustaka Utama. Jakarta.

Witono, A. 2005. Produksi Furfural dan Turunannya. Program Studi Teknik Kimia. Departemen Teknik Gas dan Petrokimia. Universitas Indonesia. http:// www.ristek.go,id 